\title{
Activated carbon quality produced by Tectona grandis wastes: activation methods and adsorption capacity
}

\author{
Qualidade de carvão ativado produzido por \\ resíduos de Tectona grandis: métodos \\ de ativação e capacidade de adsorção
}

\section{Rafaeli Valério de Lima ${ }^{1}$, Ana Clara Caxito de Araújo ${ }^{1}$, Matheus Felipe Freire Pego ${ }^{1}$, Bruno Charles Dias Soares ${ }^{1}$, Maria Lúcia Bianchi ${ }^{2}$, Paulo Fernando Trugilho ${ }^{1}$}

\footnotetext{
${ }^{1}$ Departamento de ciências florestais, Universidade Federal de Lavras, Câmpus Universitário, CP 3037, Lavras, Minas Gerais, Brasil.

${ }^{2}$ Departamento de química, Universidade Federal de Lavras, Câmpus Universitário, CP 3037, Lavras, Minas Gerais, Brasil.

e-mail: rafaeli_valerio@hotmail.com, anacaxitoengflor@hotmail.com, matheusfelipefreire@gmail.com, bruno.soares18@hotmail.com, bianchi@ufla.br, trugilho@ufla.br
}

\begin{abstract}
Activated carbons (AC) are high porosity and adsorptive carbonaceous materials. These adsorbents can be produced using different organic materials. Precursor material properties may impact their quality. This study aimed to produce activated carbon from Tectona grandis wood wastes, besides determining efficiency in adsorption of different pollutants. Chemical activation, with $\mathrm{ZnCl}_{2}\left(\mathrm{AC} \_\mathrm{ZnCl}_{2}\right)$ and $\mathrm{CuSO}_{4}\left(\mathrm{AC}_{-} \mathrm{CuSO}_{4}\right)$, and physical activation, with $\mathrm{CO}_{2}\left(\mathrm{AC}_{-} \mathrm{CO}_{2}\right)$ were performed. Activated carbons were characterized by FTIR, surface functional groups (Boehm) and surface area analysis. Moreover, ACs were tested regarding adsorption capacity of methylene blue (MB), phenol and $\mathrm{Cr}^{+6}$ ions in aqueous medium. Higher total pore volume $\left(0.62 \mathrm{~cm}^{3} \mathrm{~g}^{-1}\right)$, micropore volume $\left(0.31 \mathrm{~cm}^{3} \mathrm{~g}^{-1}\right)$ and surface area $\left(524.50 \mathrm{~m}^{2} \mathrm{~g}^{-1}\right)$ were obtained in $\mathrm{AC}_{-} \mathrm{ZnCl}_{2}$, which was also the most effective in $\mathrm{MB}$ and phenol adsorption. $\mathrm{AC}_{-} \mathrm{CuSO}_{4}$ obtained high adsorption capacity for phenol and presented functional groups different from the other $\mathrm{AC}$. $\mathrm{AC}_{-} \mathrm{CO}_{2}$ was the second with better adsorption performance for all pollutants.
\end{abstract}

Keywords: Activation process. Adsorbent. Forest wastes. Raw material.

\section{INTRODUCTION}

Activated carbon (AC) is a carbonaceous material efficiently used in many environmental remediation processes in the removal of a wide range of pollutants. AC is also commonly used in chemical, petrochemical and pharmaceutical industries, due to its high adsorption capacity [1,2]. The AC quality is governed by adsorption capacity of specific adsorbate. Adsorption capacity is mainly controlled by surface área, internal porous structure and surface chemistry [3,4], although other factors can also affect such as $\mathrm{pH}$, Temperature, contact time, stirring speed, internal structure and adsorbate properties.

In Brazil, activated carbon production is not enough to supply national demand, leading the country to significant dependence on international product. The majority of activated carbon used in Brazil are imported. The production of appropriated AC is required, both in quality and quantity. The largest Brazilian AC producers currently use cattle bones and coconut endocarp as precursor materials. As a result, they are facing difficulties in finding raw materials and, at the same time, some precursors have many drawbacks such as variation in properties, high production cost and logistical-supply challenges. In addition, the global market of activated carbon is increasing quickly, as well as new application potentialities [5]. Thus, evaluation of 
new precursor materials, with potential to produce quality and low cost activated carbon is desired.

Tectona grandis (teak) is a noble wood species from the Lamiaceae family, native to Asia and introduced in Brazil in the beginning of 20th century [6]. Teak wood production involves silvicultural techniques such as pruning and thinning. At teak stands, about $60 \%$ of the wood produced becomes waste and remains in the field, generating about $250 \mathrm{~m}^{3} \mathrm{ha}^{-1}$ (gross volume), of thin logs, branches and twigs during the entire production cycle. As a consequence, significant volume of unused wood is generated during the teak production. This wood could be better harnessed and become raw material for some products.

Then, teak wastes could be used as raw material in the activated carbon production attaining environmental (waste management) and economic gains (high value product). This new precursor material couldsupply, at least partially, the raw material demand for activated carbon production in Brazil. Activated carbons produced by teak wastes can become an alternative precursor material due to many properties found in AC made from wood, such as high surface area, pore structure and surface chemistry.

Therefore, this study aimed to evaluate the potential of the use of wastes from harvesting teak plantations and produce activated carbons from these materials, using physical and chemical activation methods and determine the AC efficiency in the adsorption of different pollutant molecules.

\section{MATERIAL AND METHODS}

\subsection{Raw material and sample collection}

The precursor material used for activated carbon production in this study was composed of thin logs, branches and top boles from the thinning of a Tectona grandis (teak) commercial exploitation. Stands were homogenous and belonged to the Refloresta Reflorestadora Ltda. Company located in Alta Floresta, Mato Grosso state. The trees were 18 years old. Samples were collected in the autumn season.

Three trees were randomly selected from the teak stands. From each tree, two samples from branches and log top were collected, totaling 6 samples. Cross sectional wood discs (5 $\mathrm{cm}$ in thickness) were sawed in 3 positions of the samples (10,50 and $90 \%$ of the samples length). Wood discs were then divided in small wedges and charred for activated carbon production.

The illustration and summarize of the experimental design are showed in Figure 1.

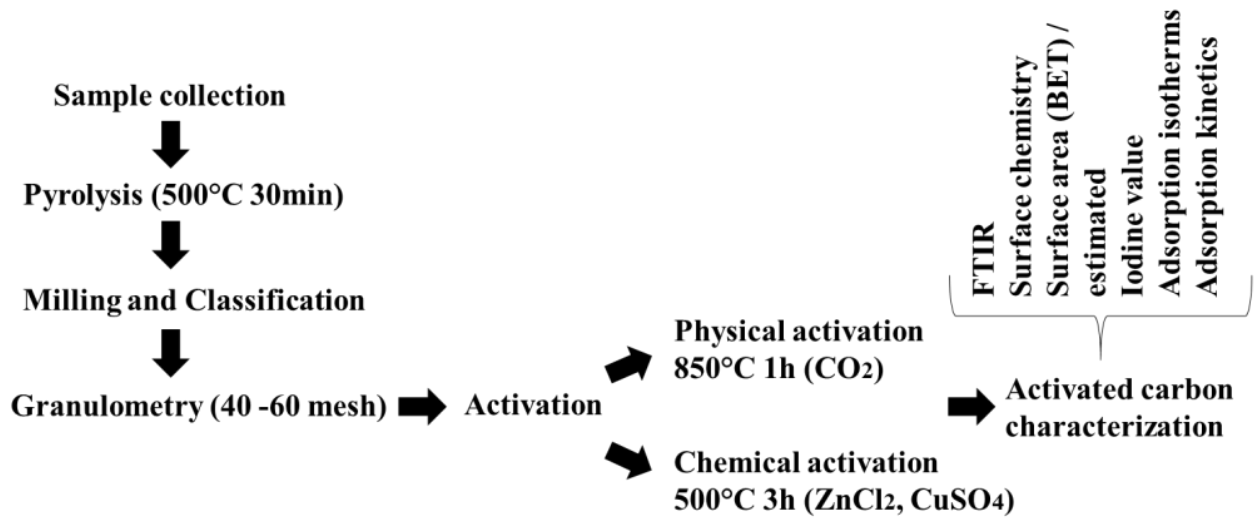

Figure 1: Experimental design of the study.

\subsection{Pyrolysis and activation}

Pyrolysis was performed in a muffle furnace (Quimis, model Q318M), with atmospheric air (low oxygen content) and initial temperature of $100{ }^{\circ} \mathrm{C}$. The temperature was raised up to $500{ }^{\circ} \mathrm{C}$, at a heating rate of $100{ }^{\circ} \mathrm{C} \mathrm{h}^{-1}$ and residence time of 30 minutes. Material was placed in metal tubes during pyrolysis. After carbonization, the material was manually milled and classified in laboratory sieves. The fraction which passed through 40 mesh sieves and was held in 60 mesh sieves was selected for activated carbon production. This fraction was selected based in previous published studies, which studies the effect of particle size in adsorption [7-9] 
Three different teak sample activations, one physical and two chemicals, were performed. Physical activation was performed in a cylindrical electric furnace, with carbon dioxide $\left(\mathrm{CO}_{2}\right)$ at $150 \mathrm{~mL} \mathrm{~min}^{-1}$ flux, temperature of $850{ }^{\circ} \mathrm{C}$, heating rate of $10^{\circ} \mathrm{C} \mathrm{min}{ }^{-1}$ and residence time of $60 \mathrm{~min}$.

Activation agents, zinc chloride $\left(\mathrm{ZnCl}_{2}\right)$ and copper sulphate $\left(\mathrm{CuSO}_{4}\right)$, were used in the chemical activation. Carbonized, milled and graded materials were impregnated with an activating agent $\left(\mathrm{ZnCl}_{2}\right.$ or $\left.\mathrm{CuSO}_{4}\right)$ and dissolved in distilled water at a 1:1 ratio (wt/wt). The materials were then dried in a digital drying oven (Marconi, model MA033) for 24 hours at $103 \pm 2{ }^{\circ} \mathrm{C}$, and subjected to heating at $10^{\circ} \mathrm{C} \mathrm{min}^{-1}$ up to $500{ }^{\circ} \mathrm{C}$, with residence time of 3 hours, under $\mathrm{N}_{2}$ atmosphere $\left(100 \mathrm{~mL} \mathrm{~min}^{-1}\right)$ in a cylindrical electric furnace. After activation the materials were washed with heated hydrochloric acid solution $2 \mathrm{~mol} \mathrm{~L}^{-1}$, and with distillated water up to neutral $\mathrm{pH}$ of 7 . Finally, the ACs were dried in the same digital drying oven at $103 \pm 2{ }^{\circ} \mathrm{C}$ for 24 hours.

\subsection{Activated carbon characterization}

Fourier transform infrared spectroscopy analysis (FTIR) was performed in an IRAffinity- Shimadzu equipment, with spectral band of 400 to $4000 \mathrm{~cm}^{-1}, 4 \mathrm{~cm}^{-1}$ resolution and 32 scans. Samples were prepared in the form of $\mathrm{KBr}$ pellets in 99:1 ratio.

Surface chemistry analysis was performed according to BOEHM [10]. Boehm titration was used to identify and quantify some surface functional groups of AC. $0.25 \mathrm{~g}$ de AC was placed under agitation with 10 $\mathrm{mL}$ of $\mathrm{NaHCO}_{3} 0.05 \mathrm{~mol} \mathrm{~L}{ }^{-1}$ during 24 hours. Same process was performed using $\mathrm{Na}_{2} \mathrm{CO}_{3}$ e $\mathrm{NaOH}(0.05 \mathrm{~mol}$ $\left.\mathrm{L}^{-1}\right)$. Then, $\mathrm{AC}$ were filtered in paper $\left(80 \mathrm{~g} \mathrm{~m}^{-2}\right.$ and $205 \mu \mathrm{m}$ thickness $)$ and $5 \mathrm{~mL}$ was taken. In aliquots containing $\mathrm{NaOH}$ e $\mathrm{NaHCO}_{3}, 10 \mathrm{~mL}$ of $\mathrm{HCl} 0.05 \mathrm{~mol} \mathrm{~L}^{-1}$ was added and in $\mathrm{Na}_{2} \mathrm{CO}_{3}, 15 \mathrm{~mL}$ of $\mathrm{HCl} 0.05 \mathrm{~mol} \mathrm{~L}^{-1}$ was added. After, samples were placed under $\mathrm{N}_{2}$ flow for 2 hours. The titration was performed using standard solutions of $\mathrm{NaOH}$ and $\mathrm{HCl} 0.05 \mathrm{~mol} \mathrm{~L}^{-1}$. The analysis was performed in a Metrohm potentiometric titrator (Titrando 888 model).

Surface area was obtained by adsorption and desorption $\mathrm{N}_{2}$ isotherms at $77 \mathrm{~K}$, by the BET (BrunauerEmmet-Teller) method in an Autosorb-1- Quantachrome equipment.

Furthermore, the surface area accessible to the iodine molecule was estimated according to Standard Test Method - D 4607-94 [11]. Another way to estimate the surface area of AC is thought methylene blue adsorption. The surface area accessible to methylene blue molecule was determined by Equation 1 .

$$
\mathrm{S}_{\mathrm{MB}}=1000 . \mathrm{S}_{\mathrm{MB}^{\circ} \cdot \mathrm{q}_{\mathrm{m}}}
$$

Where, $\mathrm{S}_{\mathrm{MB}}=\mathrm{AC}$ area accessible to methylene blue, $\mathrm{S}_{\mathrm{MB}^{\circ}}=$ Methylene blue surface area $\left(1.93 \mathrm{~m}^{2} \mathrm{mg}^{-1}\right)$; and $\mathrm{qm}=\mathrm{MB}$ maximum adsorption capacity in activated carbon samples [12].

By using surface area data accessible to iodine and methylene blue molecules, it was possible to obtain estimated surface area using multiple regression, as described by NUNES and GUERREIRO [13]. BET surface area, total pore volume and micropores were determined by the Structural Characterization of AC software. Samples were initial treated at $250{ }^{\circ} \mathrm{C}$ under $\mathrm{N}_{2}$ flow for 12 hours. Surface area was calculated by BET method and pore distribution calculated by DFT.

In adsorption tests, the $\mathrm{AC}$ were tested with organic compounds (methylene blue and phenol) and $\mathrm{Cr}^{+6}$ ions, representing a varied class of pollutants found in liquid effluents.

Adsorption isotherms were obtained using $10 \mathrm{mg}$ of adsorbent (AC) and $10 \mathrm{~mL}$ of adsorbates at different solutions concentration $\left(25-1000 \mathrm{mg} \mathrm{L}^{-1}\right)$. Samples were kept under $100 \mathrm{rpm}$ shaking, during 24 hours at room temperature $\left(25 \pm 2{ }^{\circ} \mathrm{C}\right)$. The samples were then centrifugated $(2000 \mathrm{rpm}$ and $5 \mathrm{~min})$ and the remaining concentration was monitored by UV-visible, (Biosystems SP-2000 UV) at wavelengths of $665 \mathrm{~nm}$ for methylene blue, $270 \mathrm{~nm}$ for phenol and $430 \mathrm{~nm}$ for $\mathrm{Cr}^{+6}$.

The Langmuir and Freundlich non-linear isotherms were used to fit the equilibrium data.

$10 \mathrm{mg}$ of activated carbons and $10 \mathrm{~mL}$ of $\mathrm{MB}$, phenol and $\mathrm{Cr}^{+6}$ at a $50 \mathrm{mg} \mathrm{L}^{-1}$ solution concentration were used for adsorption kinetics. The conditions such shaking, temperature, wavelength were used in the same way as the isotherm. At predetermined time intervals, aliquots from the solutions were withdrawn and the concentration determined. Same equipment and wavelengths reported in adsorption isotherms was also used for adsorption kinetics.

\section{RESULTS AND DISCUSSION}




\subsection{Activated carbon characterization}

Table 1 shows total acidity and quantity of some surface functional groups of the ACs prepared.

Table 1: Functional groups and total acidity determined by BOEHM method

\begin{tabular}{c|c|c|c}
\hline \multirow{2}{*}{$\begin{array}{c}\text { FUNCTIONAL GROUP } \\
\left.\mathbf{( m m o l ~ g}^{-1}\right)\end{array}$} & AC_CO $_{\mathbf{2}}$ & AC_ZnCl $_{\mathbf{2}}$ & AC_CuSO $_{\mathbf{4}}$ \\
\cline { 2 - 4 } Total acidity & 1.0596 & 1.1518 & 1.2911 \\
\hline Carboxylic acids & 0.7222 & 0.7937 & 0.8215 \\
\hline Lactones & 0.3082 & 0.2664 & 0.2624 \\
\hline Phenols & 0.0293 & 0.0917 & 0.2072 \\
\hline
\end{tabular}

The activated carbons presented similar total acidity, however an increasing tendency in the chemically activated materials is observed. $\mathrm{AC}_{-} \mathrm{CO}_{2}$ (physically activated) presented lower acidity. According to DASTGHEIB and KARANFIL [14], acidity decreases in physically activated materials at temperatures higher than $700{ }^{\circ} \mathrm{C}$. This is explained by higher oxygen removal from the surface, decreasing the quantity of acid groups which have oxygen atoms in their structure. Acidity was also related to quantity of carboxylic acids groups on the $\mathrm{AC}$, since carboxylic acids are strong acids and play a role in acidity.

Generally, among surface groups, carboxylic acid groups were found in higher quantity among treatments $\left(0.7\right.$ to $\left.0.8 \mathrm{mmol}_{\mathrm{gAC}}{ }^{-1}\right)$. Lactone and phenol groups are considered as relatively weak acids and dissociate at high $\mathrm{pH}$ values. These groups can improve the adsorption process, mainly if $\mathrm{pH}$ is in the acidic range, favoring group protonation when presented in high concentrations, compared to other functional groups [15].

AC_CuSO ${ }_{4}$ presented a different behavior compared to the others AC prepared, with higher total acidity, carboxylic acids and phenol groups.

The surface chemistry is different compared to commercial activated carbons and others AC produced using different methods [16]. Authors found lower values for carboxylic acids and lactones $\left(0.43 \mathrm{mmol} \mathrm{g}^{-1}\right.$ and $0.01 \mathrm{mmol} \mathrm{g} \mathrm{g}^{-1}$, respectively) and higher values for phenolic hydroxyls $\left(0.33 \mathrm{mmol} \mathrm{g} \mathrm{g}^{-1}\right)$. Difference are probably related to material used for AC production and process conditions (pyrolysis and activation). However, values found in this study are in consonance with the normal range and differences are related to raw material properties, treatments, pyrolysis and activation process.

FTIR spectra of precursor materials and activated carbons are presented in Figure 2.

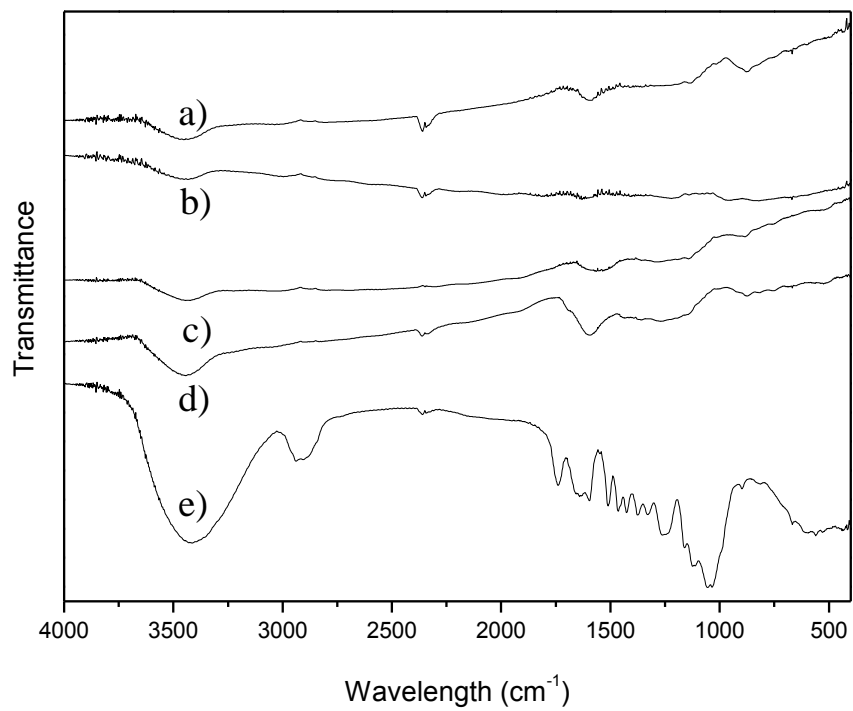

Figure 2: FTIR spectrum of $\mathrm{AC}_{-} \mathrm{CuSO}_{4}(\mathrm{a}), \mathrm{AC}_{-} \mathrm{CO}_{2}(\mathrm{~b}), \mathrm{AC}_{-} \mathrm{ZnCl}_{2}$ (c), carbonized precursor (d) and precursor (e). 
The FTIR spectrum of precursor (Figure 2:e) presented a wide band at approximately $3400 \mathrm{~cm}^{-1}$, corresponding to axial -O-H deformation, very present in carbohydrates. The FTIR spectrum also presented signals at $2930 \mathrm{~cm}^{-1}$, which characterize symmetrical and asymmetric vibrations of $-\mathrm{CH}_{2}$ - groups; a band in the $1730 \mathrm{~cm}^{-1}$ region, characterizing $\mathrm{C}=\mathrm{O}$ carbonyl stretching; a band close to $1600 \mathrm{~cm}^{-1}$, related to $\mathrm{C}=\mathrm{C}$ bond stretching of aromatic groups and water absorption; a band close to $1230 \mathrm{~cm}^{-1}$ is related to lignin aromatic ring vibration and bands between 1000 and $1050 \mathrm{~cm}^{-1}$ are assigned to $\mathrm{C}-\mathrm{O}$ stretching from macromolecules or C-O-C from cellulose and hemicellulose [17].

AC spectra (Figure 2: a, b and c) presented a decrease in intensity of the $3400 \mathrm{~cm}^{-1}$ band, since most carbohydrates (considerable $\mathrm{OH}$ groups) are destroyed during the carbonization process. As this band also indicates physical adsorption of water, it was found in all AC spectra. A band close to $1730 \mathrm{~cm}^{-1}$ almost disappears in the AC spectra, showing a carbonyl group decrease in these materials. Bands at approximately 1600 and $1230 \mathrm{~cm}^{-1}$, related to aromatic groups, appear with less intensity in all spectra, indicating presence of these groups even after the carbonization and activation processes. The band around $2300 \mathrm{~cm}^{-1}$ can be related to presence or absence of $\mathrm{CO}_{2}$ in the samples. The band appears with high intensity in $\mathrm{AC}_{-} \mathrm{CuSO}_{4}$ and $\mathrm{AC} \_\mathrm{ZnCl}_{2}$, characterizing the release of this gas.

Table 2 shows surface area analysis of activated carbon by several methods.

Table 2: Surface area values of activated carbons obtained by different methods and pore volume.

\begin{tabular}{c|c|c|c|c|c|c}
\hline $\begin{array}{c}\text { ACTIVATED } \\
\text { CARBONS }\end{array}$ & $\begin{array}{c}\text { BET } \\
\text { ANALYSIS } \\
\left(\mathbf{m}^{\mathbf{2}} \mathbf{g}^{-1}\right)\end{array}$ & $\begin{array}{c}\text { ESTIMATED } \\
\text { BET } \\
\left(\mathbf{m}^{\mathbf{2}} \mathbf{g}^{-1}\right)\end{array}$ & $\begin{array}{c}\mathbf{S}_{\text {MB }} \\
\left(\mathbf{m}^{2} \mathbf{g}^{-1}\right)\end{array}$ & $\begin{array}{c}\text { IODINE INDEX } \\
\left(\mathbf{m g ~ g}^{-1}\right)\end{array}$ & $\begin{array}{c}\text { TOTAL } \\
\text { PORE VOL- } \\
\text { UME } \\
\left(\mathbf{c m}^{\mathbf{3}} \mathbf{g}^{-1}\right)\end{array}$ & $\begin{array}{c}\text { MICROPORE } \\
\text { VOLUME } \\
\left.\mathbf{( c m}^{\mathbf{3}} \mathbf{g}^{-1}\right)\end{array}$ \\
\hline $\mathrm{AC}_{\mathrm{AC}} \mathrm{CO}_{2}$ & 277.90 & $344 \pm 37$ & 261.01 & 268.92 & $0.42 \pm 0.05$ & $0.09 \pm 0.01(21)^{*}$ \\
\hline $\mathrm{AC}_{\mathrm{ZC}} \mathrm{CuSO}_{2}$ & 524.50 & $680 \pm 74$ & 420.30 & 724.95 & $0.62 \pm 0.08$ & $0.31 \pm 0.05(50)$ \\
\hline
\end{tabular}

$\mathrm{S}_{\mathrm{MB}}$ : $\mathrm{AC}$ area accessible to methylene blue; $*$ Values in parentheses indicate micropore volume percentage regarding total pore volume.

Higher total pore volume $\left(0.62 \mathrm{~cm}^{3} \mathrm{~g}^{-1}\right)$, micropore volume $\left(0.31 \mathrm{~cm}^{3} \mathrm{~g}^{-1}\right)$ and surface area $\left(524.50 \mathrm{~m}^{2}\right.$ $\left.\mathrm{g}^{-1}\right)$ was obtained in $\mathrm{AC} \_\mathrm{ZnCl}_{2}$. Usually, chemical activation provides micropore formation, while physical activation generates more mesoporous materials. This result can be observed comparing the micropore volume percentage of AC chemically AC_ZnCl 2 (50\%), $\mathrm{AC}_{-} \mathrm{CuSO}_{4}(43 \%)$ and physically $\mathrm{AC}_{-} \mathrm{CO}_{2}(21 \%)$ activated.

Total pore and micropore volume are different between $\mathrm{AC}$, excluding $\mathrm{AC}_{-} \mathrm{CuSO}_{4}$ and $\mathrm{AC}_{-} \mathrm{CO}_{2}$ for micropore volume. The similarity is also observed in BET, estimated BET and iodine index.

CHEN et al. [18] evaluating BET surface area of commercial activated carbon obtained $1178 \mathrm{~m}^{2} \mathrm{~g}^{-1}$, superior than all results found in this study. However, similar AC produced in laboratory presented 455, 425 and $509 \mathrm{~m}^{2} \mathrm{~g}^{-1}$ for ipê, guarapá and maçaranduba wood, via physical activation, respectively [19]. All values in Table 2 for surface area were expected considering AC produced by agricultural waste and prepared in similar conditions, as reported in literature [20-22].

\subsection{Adsorption tests}

Adsorption isotherms correlate adsorbate amount adsorbed by adsorbent mass unit (Qeq) with adsorbate remaining concentration in adsorption equilibrium (Ceq). Figure 3 presents $\mathrm{MB}$, phenol and $\mathrm{Cr}^{+6}$ adsorption isotherms for the produced activated carbons.

Higher adsorption capacity was observed in $\mathrm{AC} \_\mathrm{ZnCl}_{2}$, followed by $\mathrm{AC}_{-} \mathrm{CO}_{2}$ and $\mathrm{AC}_{-} \mathrm{CuSO}_{4}$, respectively. According to Figure 3:A, AC_ $\mathrm{ZnCl}_{2}$ presented higher $\mathrm{MB}$ adsorption efficiency, with maximum adsorption of approximately $218 \mathrm{mg} \mathrm{g}^{-1}$, a similar value, compared to commercial activated carbon $(233 \mathrm{mg} \mathrm{g}$ $\left.{ }^{1}\right)$ with higher surface area $\left(933 \mathrm{~m}^{2} \mathrm{~g}^{-1}\right)$, according to BRUM et al. [23].

The lowest MB adsorption was obtained in $\mathrm{AC}_{-} \mathrm{CuSO}_{4}\left(30 \mathrm{mg} \mathrm{g}^{-1}\right)$, even presenting a BET area (273 $\left.\mathrm{m}^{2} \mathrm{~g}^{-1}\right)$ similar to $A C_{-} \mathrm{CO}_{2}\left(278 \mathrm{~m}^{2} \mathrm{~g}^{-1}\right)$, which in turn reached $\mathrm{MB}$ adsorption of $135 \mathrm{mg} \mathrm{g}^{-1}$. The MB adsorption isotherm for $\mathrm{AC}_{-} \mathrm{CO}_{2}$ was not stabilized, denoting the presence of unsaturated sites. 
AC_ $\mathrm{ZnCl}_{2}$ presented high capacity of phenol adsorption $\left(184.82 \mathrm{mg} \mathrm{g}^{-1}\right)$, higher than Bestchem commercial activated carbon (142.86 $\left.\mathrm{mg} \mathrm{g}^{-1}\right)$, studied by CHEN et al. [18]. This evidences that this AC can be used in adsorption processes of this pollutant.
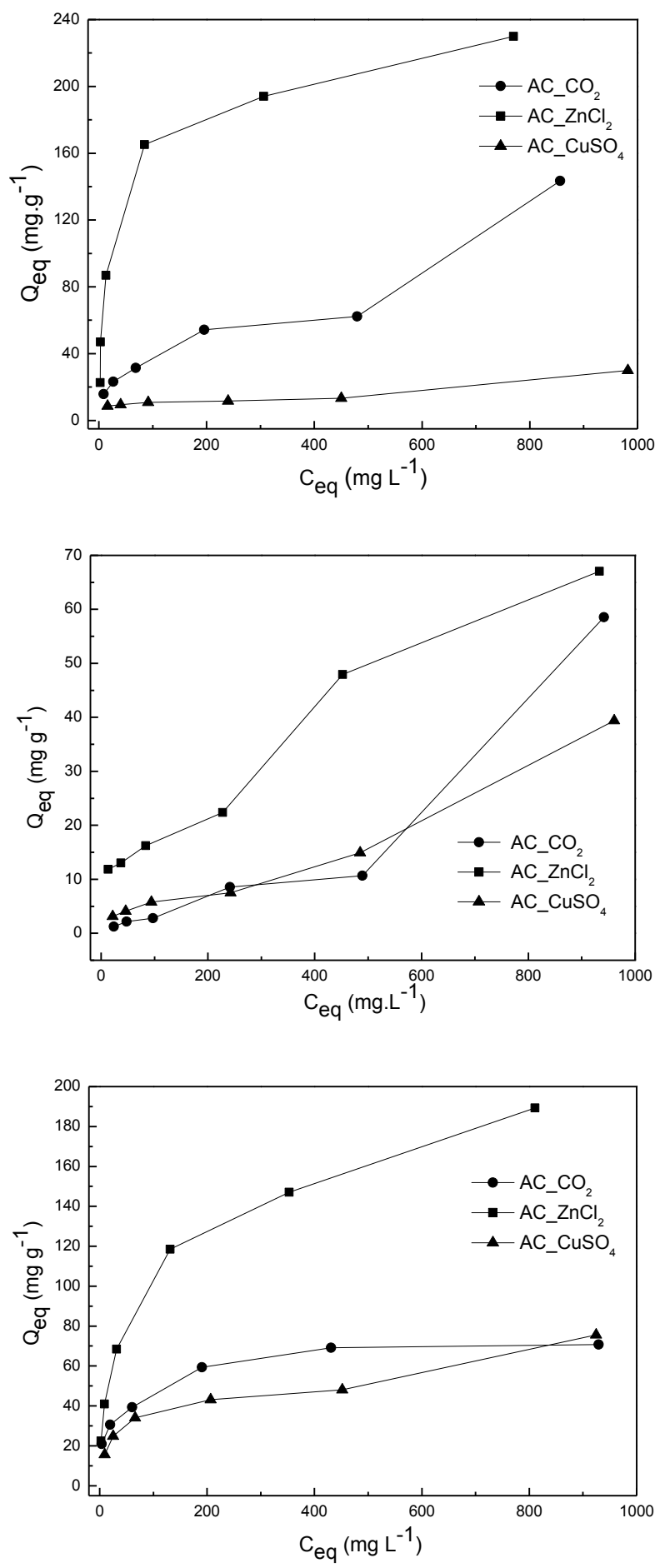

Figure 3: Methylene blue (A), phenol (B) and $\mathrm{Cr}^{+6}(\mathrm{C})$ adsorption isotherms for different ACs (10 mg of $\mathrm{AC}$, $10 \mathrm{~mL}$ of different solution concentrations, $25^{\circ} \mathrm{C}, 24 \mathrm{~h}$ ).

AC_C $\mathrm{CO}_{2}$ (physically activated at $850^{\circ} \mathrm{C}$ ) obtained phenol adsorption similar to $\mathrm{CA} \mathrm{CuSO}_{4}$ (chemically activated at $\left.500^{\circ} \mathrm{C}\right)$, demonstrating that high temperature in the physical activation $\left(\mathrm{CA}_{-} \mathrm{CO}_{2}\right)$ did not favor microporosity development, as also shown in Table 2. 
According to TAY et al. [24], high final temperature produces higher porosity AC. However, temperatures above $600^{\circ} \mathrm{C}$ can lead to a significant porosity drop, probably because of the agglutination effect, which is characterized by destruction of adjacent pore walls, expanding micropores to meso and macropores.

Figure 3:C presents the $\mathrm{Cr}^{+6}$ adsorption isotherm. Higher and lower adsorption amounts were obtained by $\mathrm{AC} \_\mathrm{ZnCl}_{2}$ and $\mathrm{AC} \_\mathrm{CuSO}_{4}$, respectively.

The adjustment parameters of Langmuir and Freundlich adsorption models are shown in Table 3. Adsorption isotherms of $\mathrm{AC}_{-} \mathrm{CO}_{2}$ and $\mathrm{AC}_{-} \mathrm{CuSO}_{4}$ were better fitted to the Freundlich model, independent of adsorbate. $\mathrm{AC}_{2} \mathrm{ZnCl}_{2}$ was better fitted to the Freundlich model only for phenol and $\mathrm{Cr}^{+6}$ adsorbates. This suggest that the adsorption process occurs in a heterogeneous surface, considering that adsorption sites have different adsorption energies and present surface variations [25]. $\mathrm{AC}_{-} \mathrm{ZnCl}_{2}$ was better fitted to the Langmuir model for MB, suggesting the adsorption process occurs in a homogeneous surface, and adsorption occurred in adsorbent specific sites.

$\mathrm{AC} \_\mathrm{ZnCl}_{2}$ and $\mathrm{AC} \_\mathrm{CO}_{2}$ have different adsorptive capacities (qm) for the three adsorbents used. However, both ACs adsorb MB in a higher amount, followed by phenol and $\mathrm{Cr}^{+6}$, respectively. $\mathrm{AC}_{-} \mathrm{CuSO}_{4}$ has different behavior, because of its greater phenol adsorptive capacity and qm similar to $\mathrm{AM}$ and $\mathrm{Cr}^{+6}$.

Data of adsorbate amount adsorbed per activated carbon area (Ads/area, Table 3) shows that, despite AC_ $\mathrm{CO}_{2}$ having less surface area (SBET) and $\mathrm{MB}$ maximum adsorption (qm) than $\mathrm{CA}_{-} \mathrm{ZnCl}_{2}$, physically activated $\mathrm{AC}$ adsorbed more methylene blue per square meter of $\mathrm{AC}\left(0.49 \mathrm{mg} \mathrm{m}^{-2}\right.$ against $0.41 \mathrm{mg} \mathrm{m}^{-2}$ for chemically activated AC.

Table 3: Langmuir and Freundlich parameters for methylene blue, phenol and $\mathrm{Cr}+6$ adsorption.

\begin{tabular}{|c|c|c|c|c|c|c|c|c|c|c|c|c|}
\hline \multirow{2}{*}{ ADSORBATE } & \multirow{2}{*}{$\begin{array}{l}\text { ACTIVATED } \\
\text { CARBON }\end{array}$} & \multirow{2}{*}{$\begin{array}{c}\text { ADS/AREA } \\
\mathrm{mg} \mathrm{m}^{-2} \\
\end{array}$} & \multicolumn{5}{|c|}{ LANGMUIR PARAMETERS } & \multicolumn{5}{|c|}{ FREUNDLICH PARAMETERS } \\
\hline & & & $q_{m}$ & $\varepsilon$ & $\mathrm{K}_{\mathrm{L}}$ & $\varepsilon$ & $\mathbf{R}^{2}$ & $\mathrm{~K}_{\mathrm{F}}$ & $\varepsilon$ & $1 / n$ & $\varepsilon$ & $\mathbf{R}^{2}$ \\
\hline \multirow{3}{*}{ MB } & $\mathrm{AC} \_\mathrm{CO}_{2}$ & 0.49 & 135.24 & 118.48 & 0.00 & 0.04 & 0.70 & 1.74 & 1.74 & 0.64 & 0.15 & 0.91 \\
\hline & AC_Z $\mathrm{ZnCl}_{2}$ & 0.41 & 217.77 & 11.31 & 0.05 & 0.01 & 0.97 & 41.16 & 10.32 & 0.26 & 0.04 & 0.93 \\
\hline & $\mathrm{AC}_{-} \mathrm{CuSO}_{4}$ & 0.11 & 30.29 & 11.96 & 0.00 & 0.00 & 0.58 & 1.63 & 1.21 & 0.40 & 0.12 & 0.70 \\
\hline \multirow{3}{*}{ Phenol } & AC_C $\mathrm{CO}_{2}$ & 0.25 & 70.55 & 5.91 & 0.03 & 0.01 & 0.86 & 16.74 & 2.77 & 0.22 & 0.02 & 0.94 \\
\hline & AC_ZnCl 2 & 0.35 & 184.82 & 15.69 & 0.02 & 0.01 & 0.96 & 22.24 & 2.92 & 0.32 & 0.04 & 0.99 \\
\hline & $\mathrm{AC}_{-} \mathrm{CuSO}_{4}$ & 0.24 & 65.37 & 9.34 & 0.01 & 0.00 & 0.75 & 8.18 & 2.11 & 0.32 & 0.02 & 0.93 \\
\hline \multirow{3}{*}{$\mathrm{Cr}^{+6}$} & AC_CO ${ }_{2}$ & 0.15 & 43.00 & 48.21 & 0.00 & 0.00 & 0.64 & 0.00 & 0.00 & 0.00 & 0.38 & 0.93 \\
\hline & AC__ $\mathrm{ZnCl}_{2}$ & 0.13 & 67.94 & 17.77 & 0.00 & 0.00 & 0.77 & 1.36 & 0.01 & 1.36 & 0.17 & 0.96 \\
\hline & AC_CuSO ${ }_{4}$ & 0.10 & 29.00 & 39.50 & 0.00 & 0.00 & 0.71 & 0.01 & 0.69 & 0.01 & 0.08 & 0.97 \\
\hline
\end{tabular}

Ads/area $=$ adsorbate amount adsorbed per activated carbon area $\left[\mathrm{qm}\left(\mathrm{mg} \mathrm{g}^{-1}\right) / \mathrm{BET}\left(\mathrm{m}^{2} \mathrm{~g}^{-1}\right)\right] ; \mathrm{q}_{\mathrm{m}}=$ maximum adsorption amount $\left(\mathrm{mg} \mathrm{g}^{-1}\right) ; \mathrm{K}_{\mathrm{L}}=$ Langmuir constant $\left(\mathrm{L} \mathrm{mg}^{-1}\right) ; \mathrm{R}^{2}=$ Coefficient of Determination; $\varepsilon=$ standard error; $\mathrm{K}_{\mathrm{F}}=$ Freundlich constant $\left(\mathrm{mg} \mathrm{g}^{-1}\right)\left(\mathrm{L} \mathrm{g}^{-1}\right) 1 / \mathrm{n} ; 1 / \mathrm{n}=$ Freundlich parameter.

The MB isotherms of $\mathrm{AC}_{-} \mathrm{CO}_{2}$ and $\mathrm{AC}_{-} \mathrm{CuSO}_{4}$ fit to the Freundlich model, suggesting that adsorption process occurred in a heterogeneous surface, considering that adsorption sites have different adsorption energy and presented variations due to surface coverage [26]. AC_ $\mathrm{ZnCl}_{2}$ fit to the Langmuir model, suggesting that adsorption process occurred in a homogeneous surface, in which adsorption takes place through specific sites of the adsorbent. All AC fit to Freundlich model in phenol and $\mathrm{Cr}^{+6}$ isotherms, suggesting that adsorption process occurred in multilayer, in which adsorption sites are not the same.

\subsection{Adsorption kinetics}

Methylene blue adsorption kinetics $\left(50 \mathrm{mg} \mathrm{L}^{-1}\right)$ are shown in Figure 4 for the AC produced. Fast MB adsorption is observed for CA_ $\mathrm{ZnCl}_{2}$, due to filling of adsorbent active sites. The chemical activation by $\mathrm{ZnCl}_{2} \mathrm{im}$ proves pore development in the AC structure. $\mathrm{AC}_{-} \mathrm{ZnCl}_{2}$ adsorbed $99.19 \%$ of $\mathrm{MB}$. MB removal by $\mathrm{AC}_{-} \mathrm{CO}_{2}$ and $\mathrm{AC}_{-} \mathrm{CuSO}_{4}$ was low, with average removal of only $15 \%$. A sharp increase in the quantity removed ac- 
cording to increased adsorbate/adsorbent contact time was not observed. The activated carbons were already saturated (equilibrium) in approximately 500 minutes.

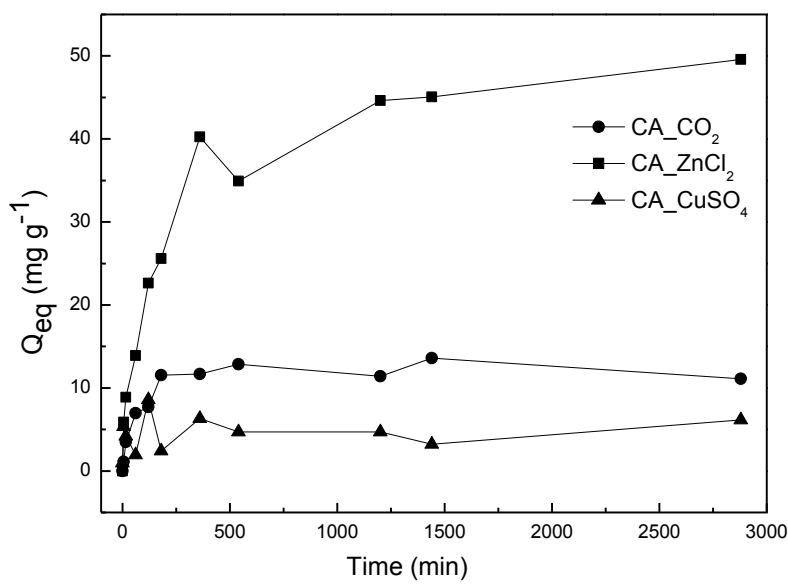

Figure 4: Methylene blue adsorption kinetics (10 mg of AC, $10 \mathrm{~mL}$ of $50 \mathrm{mg} \mathrm{L}^{-1}$ solution).

According to Figure 5, phenol removal by $\mathrm{AC} \_\mathrm{ZnCl}_{2}$ and $\mathrm{AC}_{-} \mathrm{CO}_{2}$ is initially fast, becoming gradually slow until equilibrium is reached, with removal of approximately $78 \%$. $\mathrm{AC}_{-} \mathrm{CuSO}_{4}$ has a slower initial adsorption, reaching 44\% phenol adsorption. All ACs reached adsorption equilibrium after 1500 minutes.

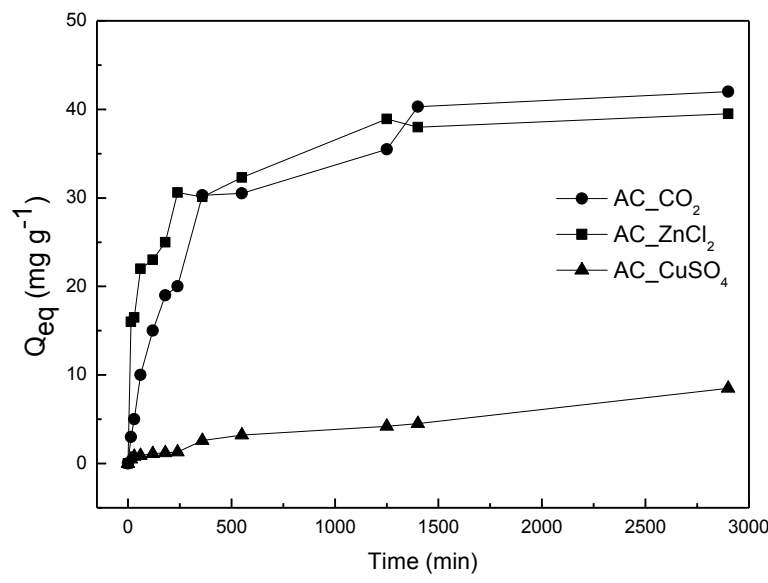

Figure 5: Phenol adsorption kinetics (10 $\mathrm{mg}$ of $\mathrm{AC}, 10 \mathrm{~mL}$ of solution $\left.50 \mathrm{mg} \mathrm{L}^{-1}\right)$.

$\mathrm{Cr}^{+6}$ adsorption kinetics curves of AC are presented in Figure 6. 


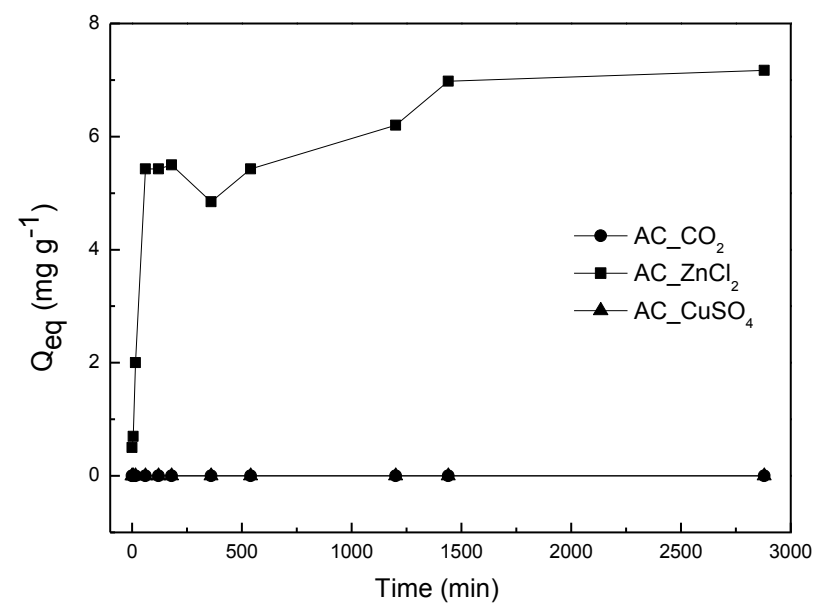

Figure 6: $\mathrm{Cr}^{+6}$ adsorption kinetics (10 $\mathrm{mg}$ of $\mathrm{AC}, 10 \mathrm{~mL}$ of solution, $50 \mathrm{mg} \mathrm{L}^{-1}$ ).

$\mathrm{Cr}^{+6}$ adsorption by $\mathrm{AC} \_\mathrm{ZnCl}_{2}$ initially occurs quickly, however the adsorption percentage is low. Adsorption equilibrium was reached after 1500 minutes. Adsorptions for $\mathrm{AC}_{-} \mathrm{CuSO}_{4}$ and $\mathrm{AC}_{-} \mathrm{CO}_{2}$ were not observed during approximately 3000 minutes. This result can be related to small surface area and pore/micropore volume of these AC as pointed out in Table 2. According to POORESMAEIL and NAMAZI [26] adsorption occurs with migration of adsorbate molecules to the outer surface of adsorbent and diffusion of adsorbate to the boundary layer. Surface and pore properties strongly affect the rate of this process.

\section{CONCLUSIONS}

Teak forest waste is a promising raw material for activated carbon production, since it has the ability to adsorb pollutants similar to commercial activated carbon, however, the activation method is a relevant factor. -Chemically activated AC (AC_CuSO4) presented characteristics and behavior different from the other ACs produced, besides presenting lower methylene blue and $\mathrm{Cr}^{+6}$ adsorption capacity. Chemically activated AC (AC_ZnCl2) presented higher surface area and adsorption capacity for all adsorbates (methylene blue, phenol and $\left.\mathrm{Cr}^{+6}\right)$. Physically activated AC (AC_CO2) presented higher basicity and was the second AC with the best adsorption capacity. Teak forest waste utilization for activated carbon production is advantageous, since, besides availability and low cost, teak wastes have suitable physical and chemical characteristics, adequate to the systems and pollutants studied.

\section{ACKNOWLEDGMENTS}

Authors would like to thank Refloresta Reflorestadora, Coordenação de Aperfeiçoamento de Pessoal de Nível Superior (CAPES) and the Wood Science and Technology Postgraduate Program.

\section{REFERENCES}

[1] DIVYASHREE A., HEGDE, G. Activated carbon nanospheres derived from biowaste materials for supercapacitor applications - a review. RSC Advances, v. 5, pp. 88339-88352, 2015.

[2] GAMAGE, S.M.K., SATHASIVAN, A.A review: Potential and challenges of biologically activated carbon toremove natural organic matter in drinking water purification process. Chemosphere, v. 167, pp. 120138, 2016.

[3] AVELAR, F.F., BIANCHI, M.L., GONÇALVES, M., et al., The use of piassava fibers (Attalea funifera) in the preparation of activated carbon. Bioresource Technology, n. 12, pp. 4639-4645, 2010.

[4] HADI, P., XU, M., NING, C., et al., A critical review on preparation, characterization and utilization of sludge-derived activated carbons for wastewater treatment. Chemical Engineering Journal, v. 260, pp. 895906, 2015.

[5] RESEARCH AND MARKETS. Activated Carbon - A Global Market Overview. 585p., 2016. 
[6] FAMATO: Federação da agricultura e pecuária do estado de Mato Grosso. 2014. Diagnóstico de florestas plantadas do Estado de Mato Grosso. Available at: <http://imea.com.br/upload/ Relatorio_final_floresta_plantada.pdf>. Access: dez. 2014.

[7] RAPOSO, F., DE LA RUBIA, M.A, BORJA, R. Methylene blue number as useful indicator to evaluate the adsorptive capacity of granular activated carbon in batch mode: Influence of adsorbate/adsorbent mass ratio and particle size. Journal of Hazardous Materials, v. 165, pp. 291-299, 2009.

[8] NEKOUEI, F., NEKOUEI, S., TYAGI, I., et al., Kinetic, thermodynamic and isotherm studies for acid blue 129 removal from liquids using copper oxide nanoparticle-modified activated carbon as a novel adsorbent. Journal of Molecular Liquids, v. 201, pp. 124-133, 2015.

[9] HAN, Y., CAO, X., OUYANG, X., et al., Adsorption kinetics of magnetic biochar derived from peanut hull on removal of $\mathrm{Cr}(\mathrm{VI})$ from aqueous solution: Effects of production conditions and particle size. Chemosphere, v. 145 pp. 336-341, 2016.

[10] BOEHM, H.P. Some aspects of the surface chemistry of carbon blacks and others carbons. Carbon, v. 32, n. 5, pp. 759-769, 1994.

[11] AMERICAN SOCIETY FOR TESTING AND MATERIALS - ASTM D 4607-94: standard test method for determination of iodine number of activated carbon. Philadelphia. 2011.

[12] STAVROPOULOS, G.G., ZABANIOTOU, A.A. Production and characterization of activated carbons from olive-seed waste residue. Microporous and Mesoporous Materials, v. 82, n. 1p. 79-85, 2005.

[13] NUNES, C.A., GUERREIRO, M.C. Estimation of surface area and pore volume of activated carbons by methylene blue and iodine numbers. Química Nova, v. 34, n. 3, p. 472-476, 2011.

[14] DASTGHEIB, S.A., KARANFIL, T. Adsorption of oxygen by heat-treated granular and fibrous activated carbons. Journal of Colloid Interface Science, v. 274, n. 1, pp. 1-8, 2004.

[15] LIU, H., SONG, H., CHEN, X., et al., Effects of nitrogen- and oxygen-containing functional groups of activated carbon nanotubes on the electrochemical performance in supercapacitors. Journal of Power Sources, v. 285, pp. 303-309, 2015.

[16] SOUZA, R.S., CARVALHO, S.M.L., GARCIA JÚNIOR, M.R.L., et al., Adsorção de cromo (VI) por carvão ativado granular de soluções diluídas utilizando um sistema batelada sob pH controlado. Acta Amazonica, v. 39, n.3, pp. 661-668, 2009.

[17] CHEN, L., WANG, X., YANG, H., et al., Study on pyrolysis behaviors of non-woody lignins with TGFTIR and Py-GC/MS. Journal of Analytical and Applied Pyrolysis, v. 113, pp. 499-507, 2016.

[18] CHEN, X., JEYASEELAN, S., GRAHAM, N. Physical and chemical properties study of the activated carbon made from sewage sludge. Waste Management, v. 22, n. 7, pp. 755-760, 2002.

[19] NOBRE, J.R.C. Produção e qualidade do carvão ativado de resíduos madereiros de espécies do estado do Pará. 2013. 116 p. Dissertação de mestrado. Universidade Federal de Lavras, Lavras.

[20] MANEERUNG, T., LIEW, J., DAI, Y., et al., Activated carbon derived from carbon residue from biomass gasification and its application for dye adsorption: kinetics, isotherms and thermodynamic studies. Bioresource Technology, v. 200, p. 350-359, 2016.

[21] YAHYA, M.A., AL-QODAH, Z., NGAH, C.W.Z. Agricultural bio-waste materials as potential sustainable precursors used for activated carbon production: a review. Renewable and Sustainable Energy Reviews, v. 46, pp. 218-235, 2015.

[22] SAYGILI, H., GÜZEL, F. High surface area mesoporous activated carbon from tomato processing solid waste by zinc chloride activation: process optimization, characterization and dyes adsorption. Journal of Cleaner Production, v. 113, pp. 995-1004, 2016.

[23] BRUM, S.S., BIANCHI, M.L., SILVA, V.L., et al., Preparação e caracterização de carvão ativado produzido a partir de resíduos do beneficiamento do café. Química Nova, v. 31, n. 5, pp. 1048-1052, 2008.

[24] TAY, J.H., CHEN, X.G., JEYASEELAN, S., et al., Optimising the preparation of activated carbon from digested sewage sludge and coconut husk. Chemosphere, v. 44, n. 1, pp. 45-51, 2001.

[25] DEBRASSI, A., TONELLI, M.C.L., RODRIGUES, C.A. Adsorção do corante vermelho congo por derivados da O-Carboximetil quitosana hidrofobicamente modificados. Química Nova, v. 34, n.5, pp. 764-770, 2011.

[26] POORESMAEIL, M., NAMAZI, H. Application of polysaccharide-based hydrogels for water treatments. Hydrogels Based on Natural Polymers, pp. 411-455, 2020. 


\section{ORCID}

Rafaeli Valério de Lima Ana Clara Caxito de Araújo Matheus Felipe Freire Pego

Bruno Charles Dias Soares

Maria Lúcia Bianchi

Paulo Fernando Trugilho https://orcid.org/0000-0001-8756-5482

https://orcid.org/0000-0001-9694-3545

https://orcid.org/0000-0002-3141-1801

https://orcid.org/0000-0002-6739-3529

https://orcid.org/0000-0001-8683-4222

https://orcid.org/0000-0002-6230-5462 